\title{
PRECONDITIONS FOR SUCCESS OF VOCATIONAL COUNSELLING OF PUPILS HAVING SPECIAL EDUCATIONAL NEEDS
}

\section{Jauniešu ar speciālām vajadzībām profesionālās konsultēšanas panākumu priekšnosacījumi}

\author{
Ingrida Baranauskienè \\ Šiauliai University, Lithuania \\ E-mail: i.baranauskiene@cr.su.lt \\ Aistė Valaikienè \\ Šiauliai University, Lithuania \\ E-mail: aistukas@mail.ru
}

\begin{abstract}
In contemporary society that is getting more and more modern maximal revelation of person's possibilities, successful adaptation to the needs of labour market have great importance, therefore, effective and timely vocational counselling has decisive influence on person's successful socialization and integration. The most vulnerable part of the society people having special educational needs (SEN) belongs to the great risk group that is at risk to experience social exclusion, become long-term unemployed and find themselves below the limit of poverty. In 2011 in Lithuania the action research was performed in which 95 students having SEN participated. During the research internal and external factors conditioning the success of vocational counselling have become distinct. Stable relations in a family, adequate evaluation of one's wishes and possibilities, early planning of vocational career are important preconditions for vocational adaptation of students having SEN.
\end{abstract}

Keywords: pupils having SEN, vocational counselling, family, adequate evaluation of one's abilities.

\section{Introduction}

By vocational counselling of children having SEN it is attempted to make a student and his/her family perceive the meaning of this counselling. Efficiently rendered services of vocational counselling are important not only to the system of education but also to labour market and a person himself/herself. Baranauskiené, Juodraitis (2008) point out that a person with disability functions in a multi-layered social field where certain regulating norms, systems of relations (business, interpersonal, group etc.), value beliefs and attitudes, competition principles that are becoming more and more prevailing are dominating. According to the authors the interaction is mutually determined when an individual acting in the field relatively has influence on the harmony of the functioning of the society and is also influenced by a social field the "pressure" of which on a person with disability might be not only more intense and stronger but also traumatizing. In assessing the probability of such possibility cognitive mechanisms become an important dimension, through which a person gets knowledge about the world and himself/herself and use gained knowledge to ensure the processes of self- 
Proceedings of the International Scientifical Conference. Volume II: Social and Special pedagogy; Health and Sport; Overviews. regulation. Vocational counselling covers many areas of activity that enable persons to determine their possibilities, competences and interests to make appropriate decisions for their future integration in labour market and social life. As Indrašienè and Grinytè state (2007) "in contemporary dynamic society which is getting more and more modern maximal revelation of person's abilities, successful adaptation to the needs of labour market, perception of the responsibility for one's own decisions have great importance. Therefore, effective and timely vocational counselling has decisive meaning on person's successful socialization".

With regard to rapid progress of science, technique and technology, with regard to constant change of the labour market the scientists present various concepts describing vocational counselling: Beresevičienè (1990) names it as vocational interests and their formation; Kučinskiene (2003) speaks about the process of getting ready for career as one of the elements of the system of vocational counselling that takes place in mainstream school. The authors pay much attention to the development of career competences - personal, social and vocational; Laužackas (2005) analyzes the concept of vocational training, vocational counselling is compared to prevocational education implementable only in school environment, when a student chooses a profession and his/her planning skills are developed. Pukelis, Garnienè (2003) analyzed the phenomenon of education for career or projecting career and distinguished the levels: education for career takes place in a family, in a nursery school, in a mainstream school through vocational counselling. Baranauskienè, Valaikiene (2010) point out that prevocational counselling is based on the development of general abilities and gaining practical primary vocational skills, practical probation of a profession. The authors distinguish the directions of prevocational education of students with special needs pointing out that prevocational training is individualized and started in a basic school with the development of general abilities and relatively "vocational" abilities, coordination of wishes and actual possibilities, introducing students having special needs with the world of activity, education of work as a value, practical testing of professions.

Therefore, striving for more favourable integration of people with disabilities and special educational needs appropriate prevocational training and counselling at schools is needed. In the report of the research "Students' vocational information, counselling and orientation at school" ordered by the Ministry of Education and Science it is indicated that vocational counselling performed at schools is not sufficient although the significance of these services at schools is theoretically actualized (Indrašienè, 2006). Baranauskienè et al. (2010) accentuate the acknowledgement and use of the role of family as a means of ensuring socialization, and, which is more important, prevocational training: in seminars, practical sessions. Attention should be paid to the relationship with the family members, taking decisions coordinating with family, accepting family members as equal partners creating both formal individual education plans for students with special needs and wider plans of life and futures. 
The aim of this article - to reveal internal and external factors that became distinct during the performed action research and condition the success of vocational counselling of pupils having SEN.

The object of the research - the preconditions for success of vocational counselling of pupils having SEN in the aspects of the role of family and pupils' assessment of their own possibilities.

\section{Methods of the research and sample characteristics}

Rendering methodical assistance of vocational counselling of pupils having SEN in 2011 the action research was performed. The duration of the research was 4 months. In creating the research methodology of project activities it was referred to the provisions of action research described in the works of Smith (2007), Usher, Bryant, and Johnston (1997), Macintyre (2002), Atkinson, Hammersley (1994), Charles (1999), Jurašaitè-Harbison (2006), Strauss, Corbin (1990), Bitinas (2006), Mills (2007) and other scientists.

Traditionally, the structure of research of activities is related to the spiral form: the way of its treatment encompasses a gradual spiral every step of which consists of the planning circle, activities and finding out fact on results of activities (Lewin; cited from Smith). Many scientists, including Elliott, Smith etc., when developing methods of research of activities, emphasise the following structural parts: raising the research problem, planning of intervention (selection of strategies, forms and methods), the process of intervention of a cyclic character (the process repeats until sufficient understanding of the problem is achieved or until the means for implementation of the solution are worked out) (Elliot, 1991), <...> the idea is to achieve the aim by repeating iterations (Smith, 2007).

In studied scientific literature, two schools of research of activities are singled out - traditional, where every step is peculiar with a spiral structure (planning, activities, analysis of results); and the theory of personal activities, where experience of an expert, specialist etc. is tested through practical activities. On the other hand, similarities are more obvious than differences between these two schools. The cyclic character as a feature that unites these theories could be singled out. Both schools emphasise that the research of activities is a cyclic process.

When developing programmes of the present project, it is recommended to ground on experience of the school of the theory of personal activities. On the other hand, it does not contradict the point of view of the traditional school too.

In the case of the present research, case study and ethnographic research was integrated into the research of activities. In other words, the principle (Kardelis, 2002; Merkys, 1999) of triangulation can be applied when the research of activities dominates. First of all, triangulation would be applied in the multi-methodical aspect (ethnographic research of activities - a case). Such choice of researchers would not only enable drawing a clearer view (Kardelis, 2002) of successful vocational counselling, but also to assess efficiency (Kardelis, 2002) of applied 
Proceedings of the International Scientifical Conference. Volume II: Social and Special pedagogy; Health and Sport; Overviews. different methods in the process of vocational counselling, e.g. what is more important - education of a pupil having SEN or systemic mediation during the overall process of vocational counselling? On the other hand, the process of vocational counselling is a complex phenomenon; that is why employment of three research methods would enable exploring the phenomenon more comprehensively.

Triangulation is also recommended to be applied from the point of view of time (participants are enquired in the beginning of activities, in the end, also, after activities are over, when they already are able to draw generalisations on experience gained during training).

The action research was performed after the plan of the service of vocational counselling that consists of 20 sessions was created: collecting information about a pupil (session 1), getting acquainted with a student, introducing a pupil with future activity and informing the parents (session 2), revealing the profession the pupil wishes (session 3), assessment of vocational abilities in the search for a suitable profession (session 4), assessment of pupils' vocational abilities in finding suitable profession (session 5), introducing a pupil with chosen profession (session 6), practical introduction of a pupil with chosen professions (sessions 7-18), introducing a pupil with the possibilities of gaining a profession (session 19), presenting useful information for the continuation of activity (session 20).

Table 1

Distribution of pupils having SEN according to gender and study programme

\begin{tabular}{|l|c|}
\hline \multicolumn{1}{|c|}{ Pupils having SEN } & N \\
\hline Girls & 33 \\
\hline Boys & 62 \\
\hline $\begin{array}{l}\text { Study according to modified programme } \\
\text { (girls) }\end{array}$ & 31 \\
\hline $\begin{array}{l}\text { Study according to modified programme } \\
\text { (boys) }\end{array}$ & 36 \\
\hline Study according to adapted programme (girls) & 9 \\
\hline Study according to adapted programme (boys) & 18 \\
\hline $\begin{array}{l}\text { Study according to general education } \\
\text { programme }\end{array}$ & 1 \\
\hline In total: & $\mathbf{9 5}$ \\
\hline
\end{tabular}

95 pupils of 14-17 years of age having SEN participated in the research, out of them 33 girls, 62 boys. 67 of the respondents study according to modified programme, 27 - according to the adapted programme, 1 student - according to general education programme (see Table 1). 


\section{Results of the research and their discussion Importance of stability of family in the stage of vocational counselling of pupils having SEN}

Vocational counselling of pupils having SEN is inseparable from the closest environment of a child - a family. The success of the integration of pupils having SEN in the society is conditioned by internal and external resources of the family, therefore, the stability of family is one of the most important factors of pupils' confidence, positive self-evaluation and creation of future, conditioning successful participation of pupils having SEN in social life. Baranauskienè, Ruškus (2004) define the concept of social participation as the participation of every person voluntarily deciding and performing certain functions and commitments, having the right and possibility to participate in everyday social activity, to create together and maintain individual sense of identity. Social participation takes place in the contexts of primary relationships: in family, with friends, at work, in leisure time, in religious activity, etc.

The results of the research have revealed insufficient support for a pupil having SEN from a family while choosing a profession. The category Unstable family relationship (see Figure 1) reveals that pupils' possibilities to strive for education and activity they want are restricted by their parents' difficult material status, one-parent family, unstable family relationships. The subcategory Material status is difficult, therefore, they will not be able to afford going to study to another town (4 statements, e.g., Family has poor material status, they would not be able to give financial support if studying in another town) is supported by the subcategory Lives with one parent or grandparent ( 5 statements, e.g., 1. He now lives with his mother and grandmother, his father died, mother has another family. 2. Mother has created a new family and lives separately.) and reveals the complication of future career planning related to the choice of profession because parents do not have possibilities to afford child's studies in another town.

As Smalskys states (2005) in contemporary Western world the costs of bringing up, educating and teaching children are very big. According to Smalskys (2005) in the democratic post-industrial contemporary world many new forms of human living have developed or previously less common forms have become distinct: living in divorce, constant change of partners, etc. A big part of children are brought up by one of the parents or with changing parents' partners. The representative of Social Research Centre established in Greece (EKKE) Laura Alipranti presented the data proving that marriage and parenthood is getting less and less related. Even 37 per cent of children in the EU are born to unmarried couples, while in some Nordic countries - almost a half (Europos parlamentas, 2011). Although 91 per cent of single parents are mothers, the term "single parents" should be used, Laura Alipranti indicates that in Sweden among persons raising children alone there are 26 per cent of men, while Rossani Trifiletti emphasized that single fathers also experience more poverty than "natural families" (Europos parlamentas, 2011). 
Proceedings of the International Scientifical Conference. Volume II: Social and Special pedagogy; Health and Sport; Overviews.

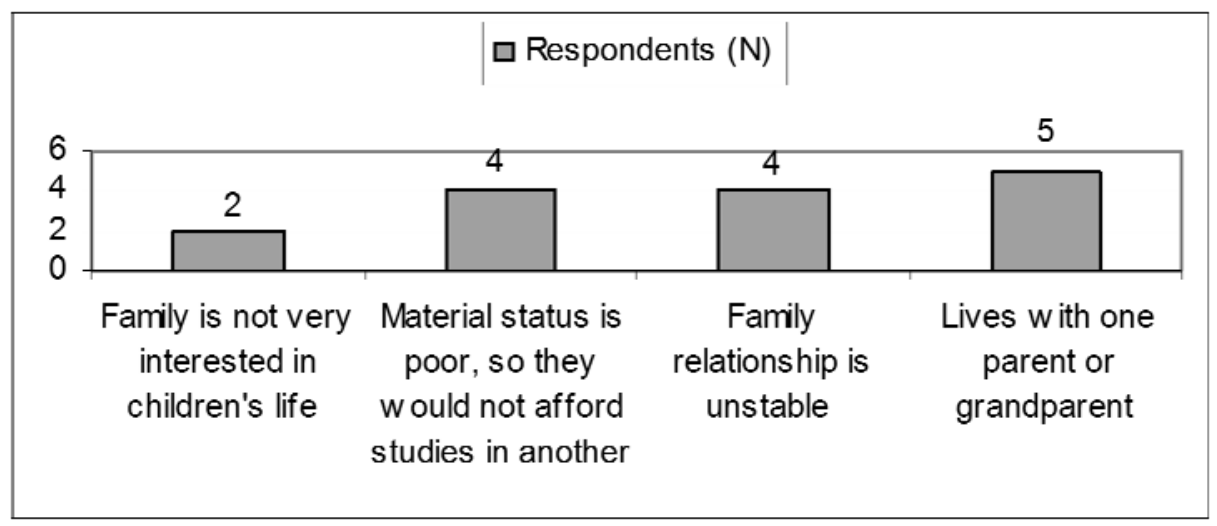

Figure 1. Unstable family relationship

In many cases divorced, widowed, teenager mothers or single mothers who adopted children risk to get into a vicious circle of poverty and exclusion. Therefore, the participants of the audition organized in the European Parliament encouraged to improve social services, to create family-friendly workplaces and ensure minimal income. According to the participants of the discussions single parents are to be given opportunities, not "helped" because grants alone will not overcome poverty. They encourage to solve the problems of accommodation and energetic poverty, to prevent the poverty spreading from generation to generation (Europos parlamentas, 2011).

In the fight against the poverty of single parents the increase of personal responsibility of the other spouse is especially important. Brita Thomsen (Alliance of Socialists and Democrats, Denmark) presenting the example of her country suggests establishing the European law on mothers' financial security after the divorce. In Denmark a divorced mother is paid by the state for supporting a child and the state collects this money from a father (Europos parlamentas, 2011). Analogous laws are carried in Lithuania, too, but the amount of support from the state for a child living with one of divorced parents does not ensure minimal living standard, and when a child becomes of lawful age, namely at the moment when the support is especially needed to get vocational education, financial support from the state is stopped.

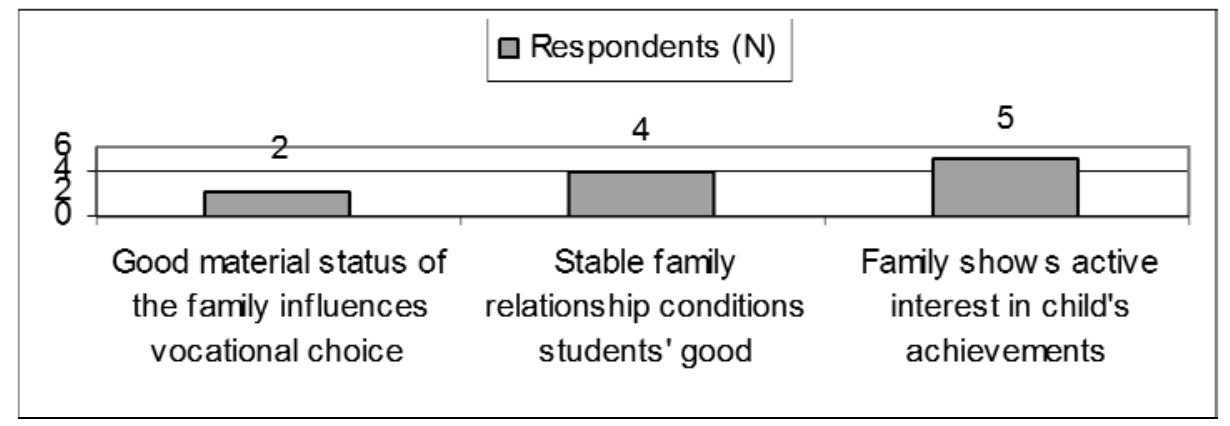

Figure 2. Good relationship in a family

The results of the research have revealed that the success of education of pupils having SEN is conditioned by the microclimate prevailing in a family. The 
subcategory Family relationship is unstable (4 statements, e.g., 1. In his family there are big problems, so he tends to retreat into himself. 2. Relationship in the family is not good, material status is difficult, both social and psychological problems influence Rūta's bad learning results.) is supported by the subcategory Family is not very interested in children's life (2 statements, e.g., It is evident that parents do not really care what is going on with their child.). Close interaction is noticed between the category Unstable family relationship and the category Good family relationship (see Figure 2) essentially reflecting the same factors that condition the success of child's vocational counselling in the aspect of family relationship. Dominating subcategory Family has active interest in child's achievements (5 statements, e.g., 1. Mother actively involves in child's education: participates in meetings, shows interest in achievements. 2. Having discussed with his parents he decided not to choose the profession of metalworker because of health problems and is thinking to study culinary.) is supported by the subcategory Stable family relationship condition students' good emotional state (4 statements, e.g., 1. The boy's family is adequate, takes care of the child. 2. Lives with both parents, mother is an educator in children's care house, father work in a construction company, gets on well with brother and father.) and shows positive impact of stable family relationship on educational achievements of pupils having SEN. The subcategory Good material status of family influences vocational choice $(2$ statements, e.g., There are no problems with the family, the family is well-off) reveals the importance of economical stability in the stage of vocational counselling of pupils having SEN, bigger possibilities in choosing a profession, because a person graduated from school may choose where to continue studies according to his/her needs.

Summing up, it is possible to state that the parents of pupils having SEN insufficiently participate in the process of children's vocational counselling. Stable, well-off, harmonious families show bigger interest in child's educational achievements, vocational prospects, however, parents show little attention to testing children's practical abilities closely related to adequate evaluation of pupils having SEN of their abilities, knowing the professions and coordination of wishes and possibilities. During the research only few pupils pointed out that they do common activity together with their parents: prepare food, help in construction works, etc.

\section{Peculiarities of evaluation of their possibilities related with future profession by pupils having SEN}

The results of the research have revealed that about 50 per cent of students having SEN adequately evaluate their possibilities related to choosing a profession in future (see Figure 3). Adequate evaluation of one's possibilities is relatable to pupil's self-perception as an employee performing work functions corresponding to the possibilities of gaining necessary education and actual abilities to perform concrete vocational activity. The subcategory Understands one's possibilities (10 
Proceedings of the International Scientifical Conference. Volume II: Social and Special pedagogy; Health and Sport; Overviews. statements, e.g., 1. Admitted that this work (advertising) is too difficult for her. 2. Parents already tell to think what I will do when I finish 10 forms, because it will be too difficult to continue to study here. 3. Sister studies administration but she would not like such a speciality, because she needs to count a lot and she does not like mathematics and is rather bad at it.) reflects inner thinking of students having SEN, adequate evaluation of their possibilities, basics of future planning and search for a suitable. Other subcategories indicated by 37 respondents (see Figure 3) reveal strong and motivated decision of pupils having SEN in choosing a concrete profession corresponding to education gained in a mainstream school.

Almost every second pupil having SEN would like to choose a speciality not corresponding to his/her possibilities. The category Inadequately evaluates one's possibilities (see Figure 4) shows the respondents' insufficient awareness about the specialities, lack of knowledge about necessary abilities, the specifics of work. The subcategory Does not evaluate one's possibilities realistically ( 7 statements, e.g., Having been explained that to gain doctor's speciality you need to study a lot, a student did not want to listen and said that he would learn while working.) reveals inadequate inner attitude of pupils having SEN towards the preparedness to work. 34 pupils having SEN indicated concrete specialities that they would like to study after graduation (see Figure 4). Pupils with SEN who have chosen speciality not realistically corresponding to their abilities are characterized by the fact that they relate their future work not to concrete activity that should be performed by a specialist, self-realization, but to secondary factors satisfying the needs of social acknowledgement, belonging to a certain social group, safety. For example, a pupil dreams about journalist's speciality because she wants to travel around the world, to see something, she likes to work with people, or a student dreams about police officer's profession because he likes policeman's uniform or would like to be a dentist because they earn a lot.

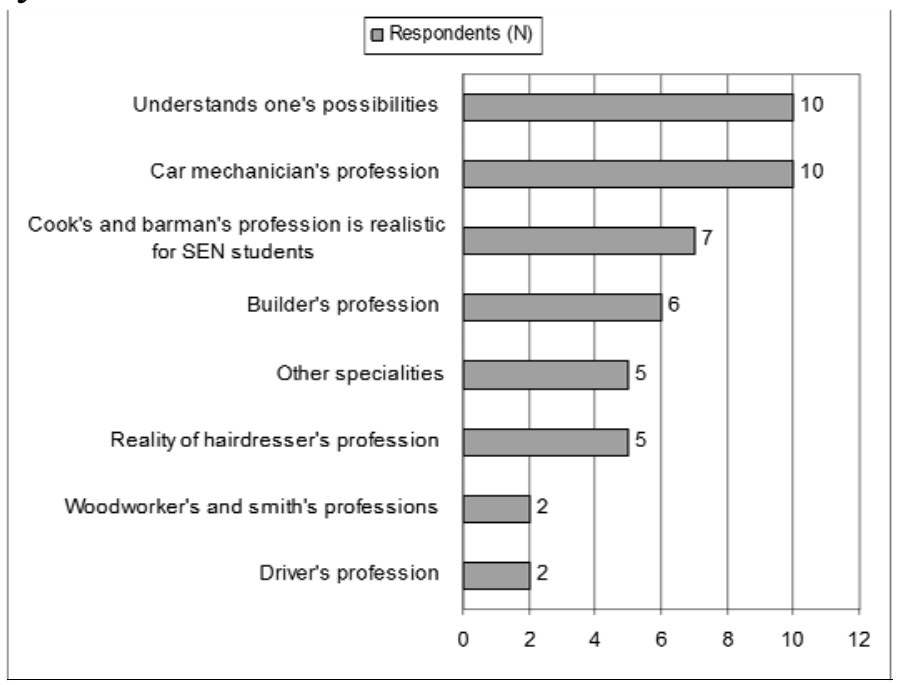

Figure 3. Pupils having SEN adequately assess their possibilities related to their future profession 
In order to achieve success of vocational counselling of pupils having SEN it is important to teach the students to orient towards specificity of workers' activity theoretically and practically introducing them to concrete activity they will have to perform in order to choose a concrete profession. Emphasizing the dependency of life quality on responsibility and motivation for work is also important helping a student to understand that safety and social acknowledgement may be ensured by well performed work of any character.

The results of action research have revealed that a SEN pupil striving to choose a profession realistically corresponding to his/her actual abilities is needed qualified assistance that cannot always be given by a family or even teachers. The closest child's environment - family not able to reconcile with actual situation may make negative impact on choosing a profession and future planning of a pupil having SEN.

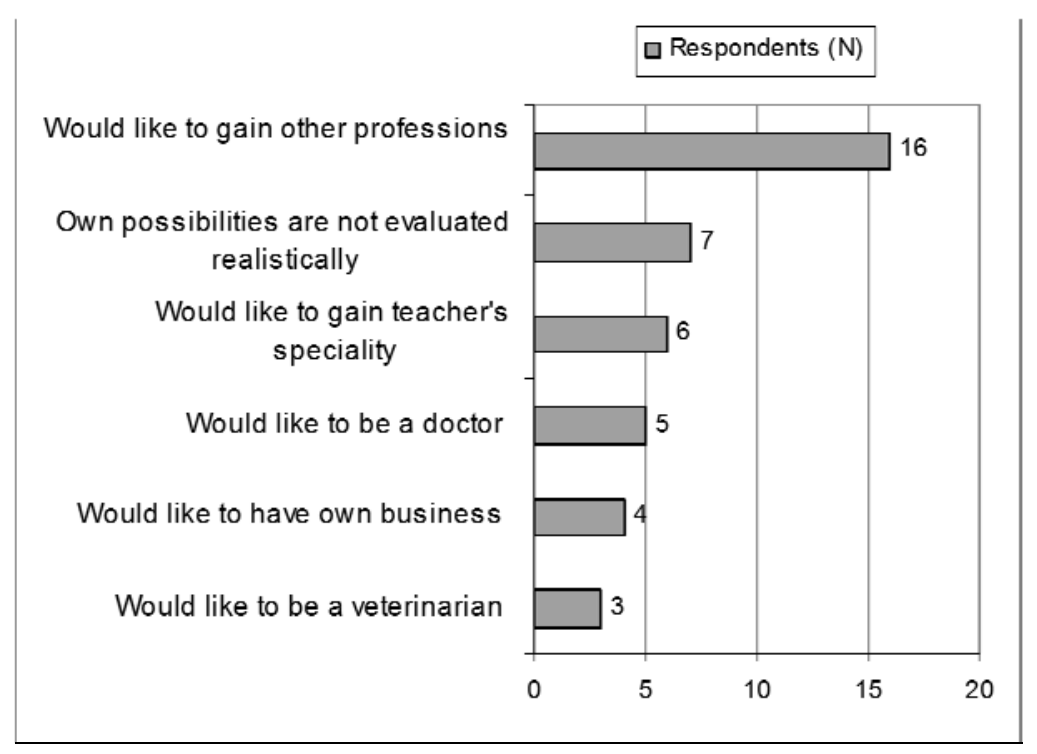

Figure 4. Inadequately assesses one's possibilities

The category Influence made by close people on choosing a profession (see Figure 5) reveals parents' controversial attitude towards child's possibilities to study. The subcategory Inadequate influence of close people on choosing a profession (3 statements, e.g., Mother's opinion and authority have big influence on her, mother wants very much her daughter to be a doctor.) is supported by the subcategory Parents inadequately assess child's abilities $(5$ statements, e.g., 1. Mother was not delighted by the idea that daughter would like to study in a vocational school. 2. Parents would like their child to strive for juridical education and become an advocate or a lawyer.) and reveals too big expectations with regard to child's future planning. Instead of looking for possibilities of the realization of the child's strongest sides, the parents raise tasks pupils will never be able to implement. 
Proceedings of the International Scientifical Conference. Volume II: Social and Special pedagogy; Health and Sport; Overviews.

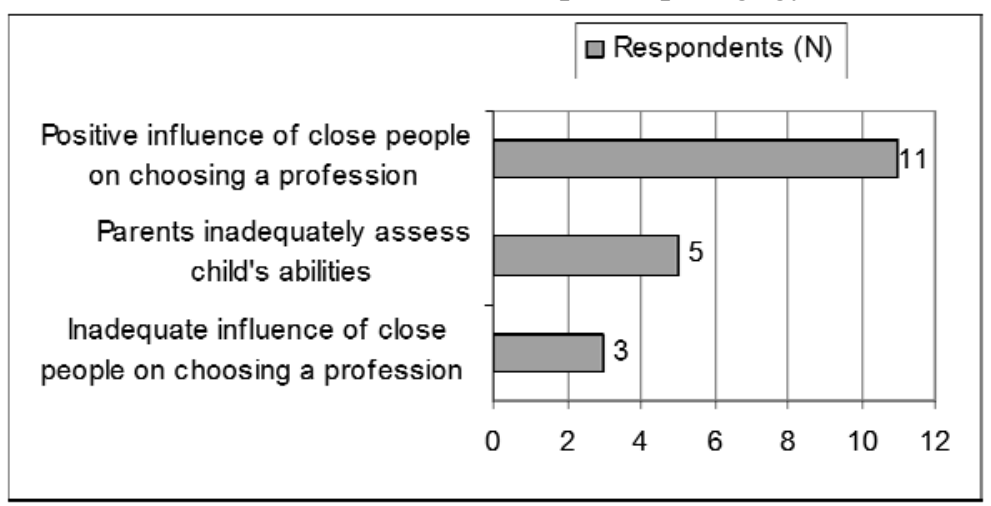

Figure 5. Influence of close people on choosing a profession

The subcategory Positive influence of close people on choosing a profession (11 statements, e.g., 1. Pupil wishes to work for "Šiaulių vandenys", install water meters, because his dad has this job and he likes it. 2. Parents advised to gain builder's profession.) reveals parents' adequate attitude towards child's abilities, their support for child's vocational choice corresponding to wishes and possibilities.

\section{Inner factors of pupils having SEN helping to choose a profession}

One of the tasks of vocational counselling of pupils having SEN is to notice and reveal child's strongest sides and on their basis look for the possibilities of student's self-realization. In this approach activity is perceived in a wide sense not only as a job but also as a factor for socialization encouraging active participation on equal basis in social life.

During the process of the action research the alteration of inner features of pupils having SEN helping to more easily integrate in the society was observed. The subcategory Actively participates in the life of school community (11 statements, e.g., successfully communicates with classmates, participates in class extracurricular activities, willingly gets involved in work activity.) shows successful process of socialization of pupils having SEN actively participating in extracurricular activity, communicating with classmates (see Figure 6).

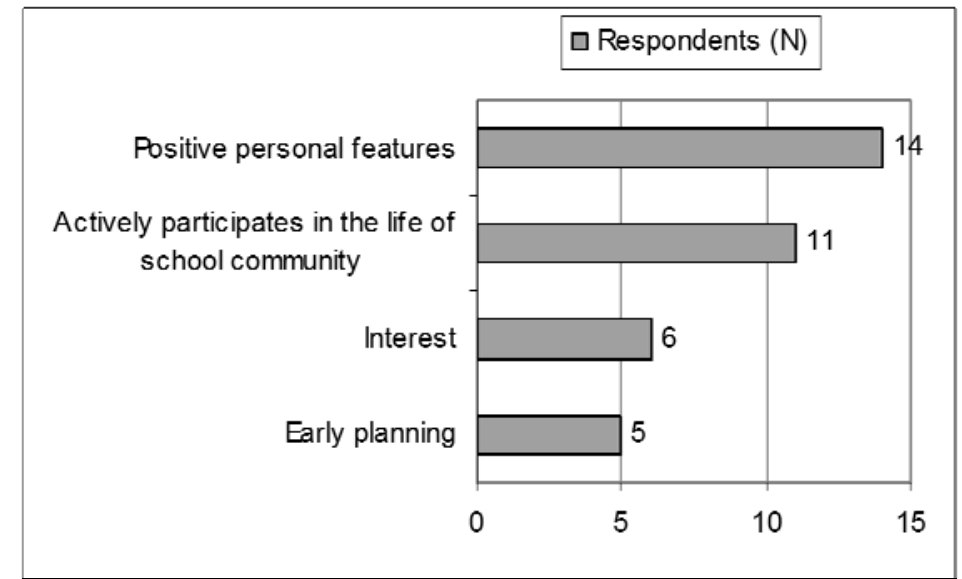

Figure 6. Positive character features helping to choose a profession 
The subcategory Interest (6 statements, e.g., For her it was more difficult to decide because she did not know whether she wanted to work with people or animals.) supports the subcategory Early planning (5 statements, e.g., What concerns the profession everything is clear what and how should be done, I will enter the confectioner's profession.) and reveals forming prospect of pupils' future planning that finishes in concrete knowing and striving for the aim.

The subcategory Positive personal features (14 statements, e.g., The boy is friendly, sociable, of joyful character.) reveals unchanging personal features of the respondents emphasizing the necessity to coordinate them to choosing the activity and profession.

\section{Conclusions}

1.The results of the research have revealed insufficient support for pupils having SEN from a family while in the process of vocational counselling. Stable, well-off, harmonious families show bigger interest in child's educational achievements, vocational prospects, gives bigger possibilities to study their chosen profession rather than unstable families. However, pupil's closest environment family because of inadequate evaluation of their child's abilities is not always competent to render necessary support. Parents instead of looking for realistic possibilities of child's integration tend to set vocational goals not corresponding to child's needs.

2.Almost every second pupil having SEN inadequately assesses his/her possibilities to strive for a chosen profession. Pupils having SEN often relate their future work not to concrete activity that should be performed by a specialist, selfrealization, but to secondary factors satisfying the needs of social acknowledgement, belonging to a certain social group, safety. Therefore, in order to achieve success in vocational counselling of pupils having SEN it is important to create the conditions for the pupils to practically test their abilities in chosen activity and in the search of a profession teach them to orient towards concrete activity a specialist should be able to perform.

3.During the process of the action research the formation of positive features of pupils having SEN helping to choose a profession corresponding to children's wishes and possibilities. One of the main axes of planning child's vocational career is interest in the activity one likes and early planning. Meanwhile, the role of the specialist of vocational counselling is to ensure appropriate coordination of personal features of pupils having SEN and a profession.

\section{Summary}

In contemporary society that is getting more and more modern maximal revelation of person's possibilities, successful adaptation to the needs of labour market have great importance, therefore, effective and timely vocational counselling has decisive influence on person's successful socialization and integration. The most vulnerable part of the society - people having special educational needs (SEN) belongs to the great risk group that is at risk to experience 
Proceedings of the International Scientifical Conference. Volume II: Social and Special pedagogy; Health and Sport; Overviews. social exclusion, become long-term unemployed and find themselves below the limit of poverty. In 2011 in Lithuania the action research was performed in which 95 pupils of the age of 14-17 having SEN participated. The aim of the research - to reveal internal and external factors that became distinct during the performed action research and condition the success of vocational counselling of pupils having SEN. The object of the research - the preconditions for success of vocational counselling of pupils having SEN in the aspects of the role of family and students' assessment of their own possibilities.

The results of the research have revealed insufficient support for pupils having SEN from a family while in the process of vocational counselling. Stable, well-off, harmonious families show bigger interest in child's educational achievements, vocational prospects, gives bigger possibilities to study their chosen profession rather than unstable families.

Almost every second pupil having SEN inadequately asseses his/her possibilities to strive for a chosen profession. Pupils having SEN often relate their future work not to concrete activity that should be performed by a specialist, selfrealization, but to secondary factors satisfying the needs of social acknowledgement, belonging to a certain social group, safety. Therefore, in order to achieve success in vocational counselling of pupils having SEN it is important to create the conditions for the pupils to practically test their abilities in chosen activity and in the search of a profession teach them to orient towards concrete activity a specialist should be able to perform.

During the process of the action research the formation of positive features of pupils having SEN helping to choose a profession corresponding to children's wishes and possibilities. One of the main axes of planning child's vocational career is interest in the activity one likes and early planning. Meanwhile, the role of the specialist of vocational counselling is to ensure appropriate coordination of personal features of pupils having SEN and a profession.

\section{Bibliography}

- Atkinson, P., Hammersley, M. (1994). Ethnography and Participant Observation. In N. K. Denzin \& Y. S. Lincoln (Eds.), Handbook of Qualitative Research. London, New Delhi: SAGE Publications.

- Baranauskienè, I.; Juodraitis. A. (2008). Neigaliuju profesine reabilitacija: sékmès prielaidos: monografija. Šiauliai : Šiaulių universiteto leidykla.

- Baranauskienè, I.; Ruškus, J. (2004). Neigaliuju dalyvavimas darbo rinkoje: profesinio rengimo ir profesinès adaptacijos squeika: monografija. Šiauliai : Šiaulių universiteto leidykla.

- Baranauskienė, I.; Valaikienė, A. (2010). Ikiprofesinis specialuju ugdymosi poreikiu turinčiu mokiniu ruošimas: galimybès, kryptys, perspektyvos. Specialiujų poreikių turinčių vaikų ugdymo bendrojo lavinimo mokyklose metodika. ISBN 978-609-430-0295.

- Beresevičienè, D. (1990). Diferencijuotas profesinis orientavimas mokykloje. Vilnius.

- Bitinas, B. (2006). Edukologinis tyrimas: sistema ir procesas. Vilnius: Kronta. 
- Elliot, J. (1991). Action Research for Educational Change. Buckingam: Open University Press.

- Europos parlamentas. Europos parlamentarai ragina gerinti vienišų motinų padètį. 2011 Prieiga per internetą: http://www.europarl.europa.eu/news/public/story_page/047112868-031-01-06-908-20110131STO12856-2011-31-01-2011/default_lt.htm.

- Charles, C. M. (1999). Pedagoginio tyrimo ìvadas. Vilnius: Alma littera.

- Indrašienè, V.; Grinytė, L. (2007). Klasès auklètojo veikla organizuojant mokiniu profesini informavima, konsultavima ir orientavima mokykloje. Socialinis ugdymas. $3(14)$.

- Indrašienė, V.; Rimkevičienė, V.; Gaigalienė, M.; Railienė, A.; Grinytè, L.; (2006). Mokiniu profesinis informavimas, konsultavimas ir orientavimas mokyklose.Vilnius. Internet access: http://www.smm.lt/svietimo_bukle/docs/tyrimai/prof_inf_paskut_paskutiniausias.pdf.

- Jurašaitè-Harbison, E. (2006). Veiksmo tyrimo vaidmuo siekiant profesionalumo. Internet access: http://gimtasiszodis.w3.lt/jurasaite.

- $\quad$ Kardelis, K. (2002). Moksliniu tyrimu metodologija ir metoda.P. 257-260

- Kučinskienè, R. (2003). Ugdymo karjerai metodologija. Klaipėda.

- Laužackas, R. (2005). Profesinio rengimo metodologija. Monografija. Kaunas.

- Macintyre, C. (2002). The Art of Action Research in the Classroom. London: David Fulton.

- Merkys, G. (1999). Eksperimentinè prieiga ugdymo tyrimuose: keliai ir klystkeliai. Socialiniai mokslai. 4 (21). P. 7-24.

- Mills, G. E. (2007). Action research: a guide for the teacher researcher. New Jersey: Pearson Education.

- Pukelis, K.; Garnienè, D. (2003). Moksleiviu ugdymas karjerai: padèties analizè ir perspektyvos bendrojo lavinimo mokykloje. Profesinis rengimas: tyrimai ir realijos.

- Smalskys V. „Gerovès valstybės“ ir socialinès viešosios politikos krypčių teoriniai aspektai. Viešoji politika ir administravimas. 2005.11, ISSN 1648 - 2603.

- Smith, M.K. (2007). Action research. The encyclopedia of informal education. Internet access: www.infed.org/reserch/b-actres.htm.

- Strauss, A.; Corbin, J. (1990). Basics of Qualitative Research Grounded Theory Procedures and Techniques. SAGE Publications.

- Usher, R.; Bryant, I.; Johnston, R. (1997). Adult Education and the Postmodern Challenge. Learning beyond the limits. London: Routledge.

\begin{tabular}{|cl|}
\hline Ingrida Baranauskienė & Šiauliai University, \\
& Faculty of Social Welfare and Disability Studies \\
& P. Višinskio str. 25, LT-76351 Šiauliai, Lithuania \\
& E-mail: i.baranauskiene@cr.su.lt \\
& Phone: + 370 41 595730 \\
\hline Aistė Valaikienė & Šiauliai University, \\
& Faculty of Social Welfare and Disability Studies \\
& P. Višinskio str. 25, LT-76351 Šiauliai, Lithuania \\
& E-mail: aistukas@mail.ru \\
\hline
\end{tabular}

